\title{
Microbial Resolution of Some Racemic Monocyclic Alcohols ${ }^{\dagger}$
}

\author{
Takayuki OrITANI and Kyohei YaMASHITA \\ Department of Agricultural Chemistry, Faculty of Agriculture, \\ Tohoku University, Sendai
}

Received June 24, 1974

\begin{abstract}
Microbial (enzymatic) hydrolysis of ( \pm )-O-acetyl allethrolone gave ( - -)-(R)-allethrolone with $(+)-(\mathrm{S})$-O-acetyl allethrolone. And microbial hydrolysis of $( \pm)$-cis and trans-2allylcyclopentyl acetates gave the low optically active cis and trans-2-allylcyclopentanols with the acetates of their antipodes. Also, the acetates of ( \pm )-primary alcohols with cyclopropane and cyclohexene rings: $( \pm$ )-chrysanthemyl alcohol, $\alpha$-cyclogeraniol, were hydrolyzed by microorganisms to give the optically active alcohols in low optical purities Further, synthesis and microbial resolution of racemic hydroxy-trimethylcyclohexanones, useful intermediate for synthesis of compounds related to carotenoids, were tried.
\end{abstract}

In previous studies, ${ }^{1,2)}$ the authors reported about biochemical resolution of $( \pm)$-alkylcyclohexanols and ( \pm -1 and 2-decalols through asymmetrical hydrolysis of their acetates by microorganisms (their esterase). In this paper, we report further on resolution of some useful racemic alcohols by the application of the above method.

(土)-Allethrolone ester of chrysanthemic acid (IXa) is called allethrin ${ }^{3)}$ and is a popular insecticide. (+)-(S)-Allethrolone (IIIa) ester of IXa shows the stronger insecticidal activity than the ester of its antipode (IIa). Chemical resolution of $( \pm$ )-allethrolone (Ia) were already performed by a tremendous treatment through semicarbazone of $( \pm)$-allethrolonyl $(+)$-transchrysanthemate. ${ }^{4}$ Now the practical resolution of Ia was achieved by the use of the biochemical method.

$( \pm)$-O-Acetyl allethrolone (Ib), prepared by acetylation of Ia with acetic anhydridepyridine, was treated with Bacillus subtilis var. Niger ${ }^{1)}$ to give a mixture of the low dextrorotatory allethrolone (IIIa) and $\mathrm{O}$ acetyl allethrolone (IIIb) accompanying with loss of some amounts. This result showed that some part of levoratatory O-acetyl al-

$\uparrow$ Biochemical Resolution of Racemic Terpenes. Part VII. This report was presented at the 45th Annual meeting of the Agricultural Chemical Society of Japan, Tokyo, April 3, 1974. lethrolone was consumed by the microorganisms. Therefore, $( \pm)$-O-acetyl allethrolone (Ib) was hydrolyzed with crude esterase ${ }^{1)}$ separated from the cultured broth of Trichoderma sp. to afford (-)-(R)-allethrolone (IIa) with $(+)-(\mathrm{S})-\mathrm{O}$-acetyl allethrolone (IIIb). Deacetylation of the latter (IIIb) with sodium methoxide in methanol or alcoholic ammonia afforded (+)-(S)-allethrolone (IIIa) $[\alpha]_{\mathrm{D}}^{20}+7.0^{\circ}$ $(\mathrm{EtOH})\left(\right.$ Ref. ; $\left.^{4}+7.3^{\circ}(\mathrm{EtOH})\right)$. Also, (土)O-formyl allethrolone (Ic) was asymmetrically hydrolyzed by esterase to give (-)-allethrolone (IIa) with (+)-O-formyl allethrolone (IIIc). The latter (IIIc) was easily deacylated by treatment with aqueous potassium bicarbonate to give $(+)$-allethrolone (IIIa), $[\alpha]_{\mathrm{D}}^{21}+6.8^{\circ}$ $(\mathrm{EtOH})$.

Next, microbial hydrolysis of ( \pm )-2-allylcyclopentyl acetates were tried as follows (Scheme 1). The reaction of the morpholine enamine of cyclopentanone with allyl bromide gave (土)-2-allylcyclopentanone (IV). Lithium aluminum hydride reduction of IV afforded (士)-2-allylcyclopentanols, which was estimated to consist of $74.3 \%$ of trans form (Va) and $25.7 \%$ of $c i s$ form (VIa), because lithium aluminum hydride reduction of 2-alkylcyclopentanones ${ }^{51}$ was proved to give mainly trans-2-alkylcyclopentanols. Microbial hydrolysis of (土)2-allylcyclopentyl acetates ( $\mathrm{Vb}, \mathrm{VIb})$, obtained by acetylation of (土)-2-allylcyclopentanols, 
by Bacillus subtilis var. Niger afforded (-)trans-2-allylcyclopentanol (VIIa), $[\alpha]_{\mathrm{D}}^{20}-4.0^{\circ}$ ( $n$-hexane), and (-)-cis-2-allylcyclopentanol (VIIIa), $[\alpha]_{\mathrm{D}}^{20}-2.5^{\circ}$ ( $n$-hexane) (contained $36 \%$ of VIIa), with the acetates of their antipode (VIIb, VIIIb), [ $\alpha]_{\mathrm{D}}^{23}+8.5^{\circ}$ (homog), with low optical rotations. The hydrolyzed cis and trans alcohols (VIIa and VIIIa) was considered to hold the ( $R$ ) configuration, as the $(R)$ type $^{1 /}$ of the acetate of $( \pm)$-2-alkylcycloalkanols was easily hydrolyzed by microorganisms.

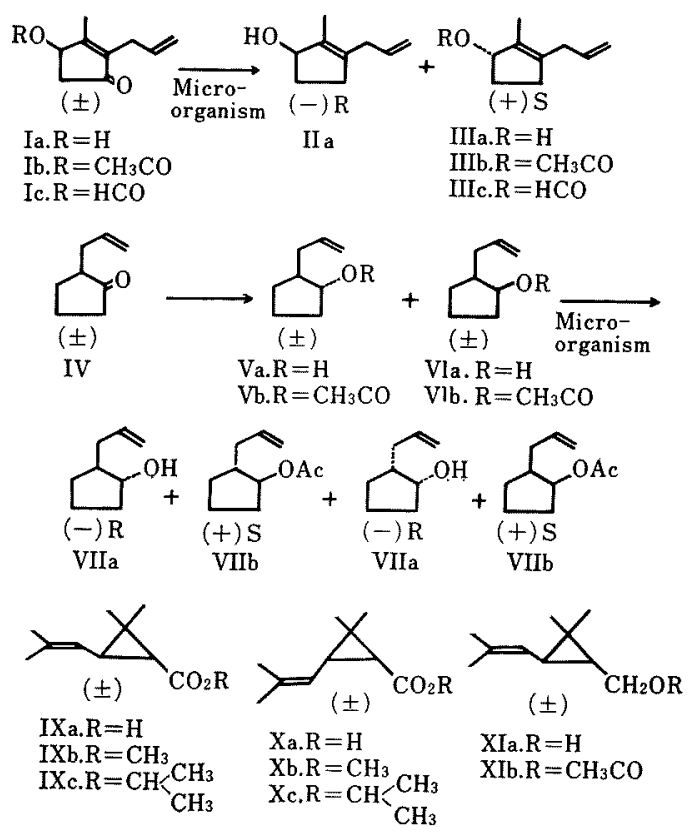

SCHEME 1.

The biochemical resolution of $( \pm)$-trans and cis-chrysanthemic acids (IXa and $\mathrm{Xa}$ ) were unsuccessful as shown below. Methyl $( \pm)$-trans and cis-chrysanthemates (IXb and $\mathrm{Xb}$ ) were treated with Trichoderma sp. until half quantity of the esters were consumed, but the separated esters ( $\mathrm{IXb}$ and $\mathrm{Xb}$ ) were optically inactive. When isopropyl ( \pm -trans and cis-chrysanthemates (IXc and $\mathrm{Xc}$ ) were treated with the cell free solution of the cultured broth of Trichoderma sp., the separated esters (IXc and $\mathrm{Xc}$ ) were also optically inactive. The acidic fractions (small amounts), separated from the cell free solution, were optically inactive and consisted of chrysanthemic acids (IXa and $\mathrm{Xa}$ ) and small amounts of unidentified compounds. This result suggested that biochemical resolution by the microorganisms ${ }^{11}$ is not suitable to resolve racemic carboxylic acids. And, enzymatic hydrolysis of $( \pm)$-trans-chrysanthemyl acetate (XIb), prepared from IXa by lithium aluminum hydride reduction and acetylation, afforded $(-)$-chrysanthemyl alcohol (XIa), ${ }^{5)}[\alpha]_{\mathrm{D}}^{19}-11.4^{\circ}$ (EtOH) (Ref. ${ }^{51}$ its antipode, $[\alpha]_{D}^{27}+46^{\circ}$ ), with $(+)$-chrysanthemyl acetate (XIb).

Further, syntheses and microbial resolution of racemic compounds (XIII, XV and XIXb), known as useful intermediates ${ }^{(\sim 8)}$ for syntheses of carotenoids, were tried as shown in Scheme 2. Asymmetrical hydrolysis of methyl $( \pm)$ $\alpha$-cyclogeranate (XII) by microorganisms was unsuccessful like the case of methyl $( \pm$ chrysanthemates (IXb and Xb). Microbial hydrolysis of $( \pm)$ - $\alpha$-cyclogeranyl acetate (XIII), prepared from XII by lithium aluminum hydride reduction and acetylation, by Bacillus subtlils var. Niger afforded (-)-(S)- $\alpha$-cyclogeraniol, ${ }^{6)}[\alpha]_{\mathrm{D}}^{20}-17.2^{\circ}($ EtOH $)\left(\right.$ Ref. $\left.^{6}\right) ;[\alpha]_{\mathrm{D}}^{25}$
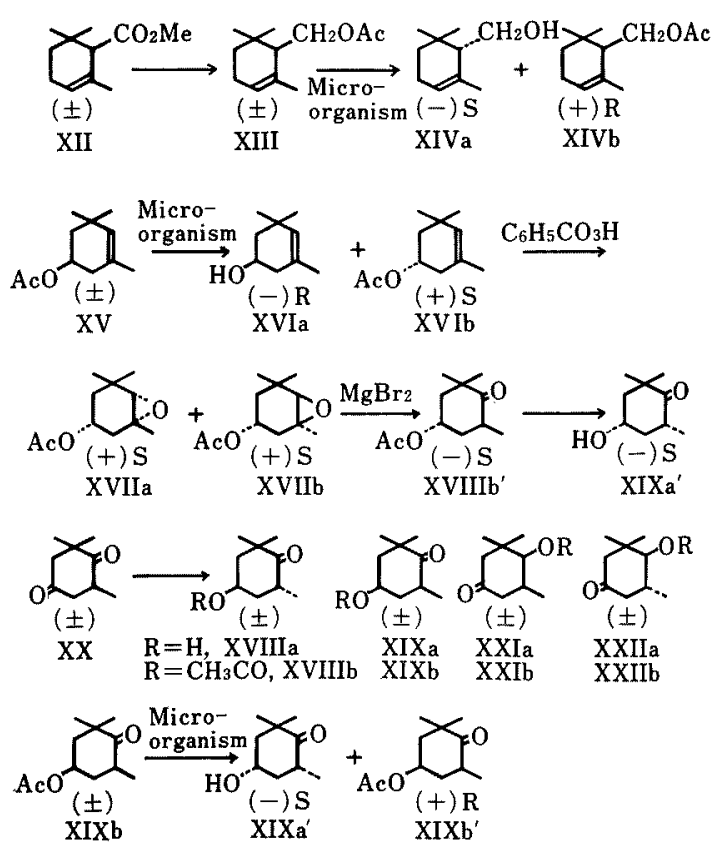

SCHEME 2. 
$\left.-132.1^{\circ}(\mathrm{EtOH})\right)$ with $(+)-(\mathrm{R})-\alpha$-cyclogeranyl acetate (XIVb) in low optical purities.

(士)-3,5,5-Trimethylcyclohex-3-enyl acetate $(\mathrm{XV})^{7)}$ was asymmetrically hydrolyzed by Bacillus subtilis var. Niger to give (-)-3,5,5-trimethylcyclohex-3-enol (XVIa), $[\alpha]_{\mathrm{D}}^{19}-144^{\circ}$ (homog) and $(+)$-3,5,5-trimethylcyclohex-3-enyl acetate (XVIb), $[\alpha]_{\mathrm{D}}^{19}+76^{\circ}$ (homog). Epoxidation of XVIb with perbenzoic acid, followed by alumina column chromatography, gave $(+)$ cis and trans-3,4-epoxy-3,5,5-trimethylcyclohexyl acetate (XVIIa and XVIIb). Rearrangement of the epoxides (XVIIa and XVIIb) with magnesium bromide-etherate afforded (-)-trans-4-acetoxy - 2, 2,6-trimethylcyclohexanone $\left(\mathrm{XVIIIb}^{\prime}\right),[\alpha]_{\mathrm{D}}^{10}-5.3^{\circ}$ ( $n$-hexane). Treatment of XVIII b' with sodium methylate in methanol gave (-)-cis-4-(S)-hydroxy-2,2,6trimethylcyclohexanone $(\mathrm{XIXa}),[\alpha]_{\mathrm{D}}^{10}-10.0^{\circ}$ $\left(\mathrm{CHCl}_{3}\right)$ in low optical purity. ${ }^{8}$ The absolute configuration of XIXa' was already determined by Mori. ${ }^{81}(+)-4-H y d r o x y-2,2$, 6-trimethylcyclohexanone, (an antipode of XIXa') was already synthesized from (-)-trans4 - hydroxy - 3, 3, 5 - trimethylcyclohexanone, which was prepared by partial hydrogenation of ( \pm )-2,2,6-trimethylcyclohexa-1,4-dione (XX) with Adams' catalyst followed by resolution through its ester with $\beta$-acetoxyetienic acid. But it was reported that partical hydrogenation of the diketone (XX) with Adams' catalyst afforded ( \pm )-4-hydroxy -2, 2, 6-trimethylcyclohexanone (XIXa). ${ }^{9}$ ' Therefore, the authors reinvestigated about the partial reduction of the diketone $(\mathrm{XX})$. Sodium borohydride (1/4 moles) reduction of the diketone (XX) in ethanol afforded hydroxy-ketones, which were separated into two main components by gas chromatography ( $20 \%$ DEGS) as shown in Fig. 1. Acetylation of the hydroxy-ketones with acetic anhydride-pyridine gave acetoxyketones, which were separated into three components (ret. time: $9.1,11.1,12.9 \mathrm{~min}$ ) by gas chromatography ( $2 \mathrm{~m} \mathrm{20 \%}$ DEGS, column temp: $175^{\circ} \mathrm{C}$, He: $20 \mathrm{cc} / \mathrm{min}$ ). Each components were separated by alumina column chromatography. Third component (ret. time: $12.9 \mathrm{~min}$ ) was identified as $( \pm)$ - trans-4-acetoxy-3,3,5-trimethylcyclohexanone $(\mathrm{XXIIb}){ }^{8}{ }^{8}$ which was also synthesized from 4-monoethyleneketal of XX by lithium aluminum hydride reduction and acetylation. First component (ret. time: $9.1 \mathrm{~min}$ ) was identical with cis-4-acetoxy-2,2,6-trimethylcyclohexanone, prepared by acetylation of XIXa', by comparison of their NMR spectra. Second component (ret. time: $11.1 \mathrm{~min}$ ) was estimated to correspond to (土)-cis-4-acetoxy-3,3,5-trimethylcyclohexanone (XXIb) by comparison of NMR spectrum of XXIb with that of XXIIb. And ( \pm )-cis-4-hydroxy-2,2,6-trimethylcyclohexanone (XIXa) was separated by silica-gel column chromatography of the above hydroxy-ketones. Partial hydrogenation of XX with Adams' catalyst in methanol gave the hydroxy-ketones, which were separated into three peaks by the gas chromatography (Fig. 2). Treatment of the hydroxy-ketones with sodium methylate followed by acetylation with acetic anhydride-pyridine gave two acetoxy-ketones (XIXb and XXIIb). Therefore, the first peak in Fig. 2 was estimated to correspond to (土)-trans-4-hydroxy-2,6,6-trimethylcyclohexanone (XVIIIa). From the above result, it was obvious that partial hydrogenation of XX with Adams' catalyst gave three hydroxy-ketones (XVIIIa, XIXa and XXIIa). Microbial hydrolysis of the acetate $(\mathrm{XIXb})$ gave (-)-cis-4-hydroxy-2,6,6trimethylcyclohexanone (XIXa'), $[\alpha]_{\mathrm{D}}^{12}-16.6^{\circ}$ $\left(\mathrm{CHCl}_{3}\right)$ with the acetate $\left(\mathrm{XIXb}^{\prime \prime}\right)$ of its antipode in low optical purities. ${ }^{8}$ But $( \pm)$-cis and trans-4-acetoxy-3,3,5-trimethylcyclohexanone (XXIb and XXIIb) were not hydrolyzed by the microorganisms. ${ }^{17}$ This means that the acetates of $( \pm)$-cycloalkanols with substituents on both carbons adjacent to their hydroxy group could not be hydrolyzed by microorganisms.

\section{EXPERIMENTAL}

Melting points and boiling points were uncorrected. $[\alpha]_{D}$ was measured by Automatic Polarimeter (Model DIP-SL, Japan Spectroscopic Co., Ltd.). NMR spectra were recorded at $60 \mathrm{MHz}$ with TMS as an internal standered (Model JMN-MH-60-II of Japan Elec- 


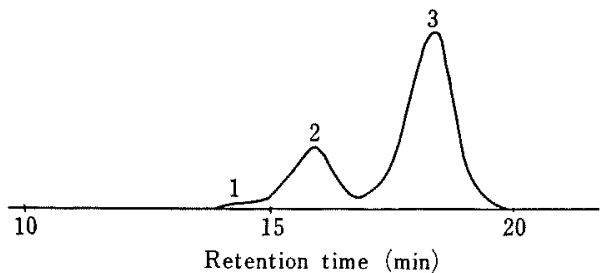

Fig. 1. Gas Chromatogram of the Hydroxy-ketones Obtained by Sodium Borohydride Reduction of ( \pm )2,2,6-Trimethylcyclohexan-1,4-dione (XX).

Column: a $3 \mathrm{~mm} \times 2 \mathrm{~m}$ stainless steel column packed with $20 \%$ polydiethyleneglycolsuccinate (DEGS). Column temp: $175^{\circ} \mathrm{C}$ isothermal, He flow rate: $20 \mathrm{cc} /$ min. 1, ( \pm )-trans-4-hydroxy-2,2,6-trimethylcyclohexanone (XVIIIa). 2, (士)-cis-4-hydroxy-2,2,6-trimethylcyclohexanone (XIXa). 3, (土)-cis and trans-4hydroxy-3,3,5-trimethylcyclohexanones (XXIa and XXIIa).

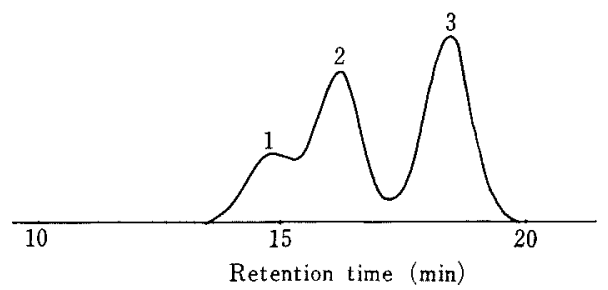

FIG. 2. Gas Chromatogram of the Hydroxy-ketones Obtained by Catalystic Hydrogenation of $( \pm)-2,2,6-$ trimethylcyclohexa-1,4-dione (XX) with Adams" Catalyst.

The same column and column condition as used in Fig. 1. 1, ( \pm )-trans-4-hydroxy-2,2,6-trimethylcyclohexanone (XVIIIa). 2, ( \pm )-cis-4-hydroxy-2,2,6-trimethylcyclohexanone (XIXa). 3, (士)-trans-4-hydroxy-3,3,5-trimethylcyclohexanone (XXIIa).

tron Optics Laboratory Co., Ltd.).

\section{1) (土)-O-Acetyl allethrolone (Ib).}

Acetylation of ( \pm )-allethrolone (Ia) (from Sumitomo Chemical Co., Ltd.) with acetic anhydride-pyridine at room temperature for $12 \mathrm{hr}$ afforded $( \pm)$-O-acetyl allethrolone (Ib), bp $135 \sim 137^{\circ} \mathrm{C} / 16 \mathrm{mmHg}, n_{\mathrm{D}}^{22} 1.4910$. IR $\nu_{\max }^{\mathrm{f} 11 \mathrm{~m}} \mathrm{~cm}^{-1} ; 3090,1745,1720,1655,1640,1235,1030$, 925.

2) Asymmetrical hydrolysis of ( \pm$)$-O-acetyl allethrolone $(\mathrm{Ib})$.

a) Microbial hydrolysis of $I b$ by Bacillus subtilis var. niger. Ib (1.5 g) was added to a cultured broth of $B$. subtilis, which was cultured in the nutrient broth medium $(100 \mathrm{ml})$. The broth was shaken at $27^{\circ} \mathrm{C}$ for 2 days. Steam-distillation of the cultured broth, followed by ether extraction, gave $540 \mathrm{mg}$ of an oil, which was chromatographed on neutral alumina. Elution with benzene afforded $350 \mathrm{mg}$ of the acetate (IIIb), $[\alpha]_{\mathrm{D}}^{20}+9.1^{\circ} \quad(c=3.8$ in $n$-hexane). Subsequent elution with ether-methanol $(9: 1)$ afforded $39.0 \mathrm{mg}$ of $(+)$-allethrolone (IIIa), $[\alpha]_{\mathrm{D}}^{20}+3.0^{\circ}(c=1.3$ in EtOH).

b) Enzymatic hydrolysis of $( \pm)$-O-acetyl allethrolone $(\mathrm{Ib}) . \quad \mathrm{Ib}(1.5 \mathrm{~g})$ was shaken with $500 \mathrm{mg}$ of crude esterase (separated from the cultured broth of Trichoderma sp., ${ }^{11}$ ) in $100 \mathrm{ml}$ of water at $27^{\circ} \mathrm{C}$ for 2 days. The mixture was extracted with ether to give an oil $(1.3 \mathrm{~g})$, which consisted of $47.0 \%$ of allethrolone (ret. time: $7.2 \mathrm{~min}$ ) and $53.0 \%$ of O-acetyl allethrolone (ret. time: $9.2 \mathrm{~min}$ ) by gas chromatographical analysis $(1.5 \mathrm{~m}$ $30 \% \mathrm{SE} 30$ on celite 545 , column temp: $180^{\circ} \mathrm{C}$, isothermal, He flow rate: $\left.17 \mathrm{cc} / \mathrm{min}\left(0.78 \mathrm{~kg} / \mathrm{cm}^{2}\right)\right)$. The oil was chromatographed on $40 \mathrm{~g}$ of neutral alumina. Elution with benzene afforded $637 \mathrm{mg}$ of $(+)$-O-acetyl allethrolone (IIb) (contaminated a small amount of unknown compound, mp 96 97 $\left.{ }^{\circ} \mathrm{C}\right),[\alpha]_{\mathrm{D}}^{21}+35.6^{\circ}(\mathrm{c}=$ 3.8 in EtOH). Successive elution with ether-methanol afforded $500 \mathrm{mg}$ of $(-)$-allethrolone (IIa), $[\alpha]_{\mathrm{D}}^{21}-6.0^{\circ}$ ( $c=3.7$ in EtOH). Deacetylation of IIIb with sodium methoxide in methanol at room temperature, followed by purification of silica-gel column chromatography, afforded $(+)$-allethrolone (IIIa), $[\alpha]_{\mathrm{D}}^{20}+7.0^{\circ} \quad(c=3.7$ in EtOH) $\left(\operatorname{Ref}^{4)}:[\alpha]_{\mathrm{D}}^{25}+7.3^{\circ}(c=13.5\right.$ in EtOH$\left.)\right)$.

\section{3) (土)-Formyl allethrolone (Ic)}

Acylation of $( \pm)$-allethrolone (Ia) with acetic formic anhydride, easily prepared from formic acid and acetic anhydride, at room temperature gave ( \pm )-formyl allethrolone (Ic). The above sample, contaminated with a small amount of $\mathrm{Ia}$, was purified by alumina column chromatography. bp $128 \sim 131^{\circ} \mathrm{C} / 17 \mathrm{mmHg}$,

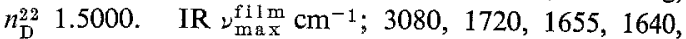
$1160,980,925,855$.

\section{4) Enzymatic hydrolysis of IC}

Ic $(1.5 \mathrm{~g})$ was shaken with $500 \mathrm{mg}$ of crude esterase in $100 \mathrm{ml}$ of water at $27^{\circ} \mathrm{C}$ for 2 days. The separated oil was chromatographed on alumina. Elution with benzene afforded $(+)$-O-formyl allethrolone (IIIc) $(187 \mathrm{mg}),[\alpha]_{\mathrm{D}}^{19}+24.1^{\circ} \quad(c=3.7$ in $\mathrm{EtOH})$, which was deacylated by treatment with $1.5 \%$ methanolic $\mathrm{KHCO}_{3}$ at room temperature for $12 \mathrm{hr}$ to give $(+)$-allethrolone (IIIa), $[\alpha]_{\mathrm{D}}^{21}+6.8^{\circ}(c=1.5$ in EtOH). Successive elution with ether-methanol afforded (-)-allethrolone (IIa) $(842 \mathrm{mg}),[\alpha]_{\mathrm{D}}^{18}-1.0^{\circ} \quad(c=8.4$ in EtOH$)$. Enzymatic hydrolysis of Ic $(2.0 \mathrm{~g})$ with $250 \mathrm{mg}$ of crude esterase in $100 \mathrm{ml} \mathrm{H}_{2} \mathrm{O}$ for 2 days afforded $847 \mathrm{mg}$ of IIIc, $[\alpha]_{\mathrm{D}}^{21}+$ $11.1^{\circ}(c=1.0 \mathrm{in} \mathrm{EtOH})$ and $968 \mathrm{mg}$ of IIa, $[\alpha]_{\mathrm{D}}^{21}-1.7^{\circ}$ $(c=9.7$ in $\mathrm{EtOH})$.

\section{5) ( \pm )-2-Allylcyclopentyl acetates (Vb, VIb)}

a) (士)-2-Allylcyclopentanone. The morpholine enamine of cyclopentanone was prepared from cyclo- 
pentanone and morpholine using $p$-toluenesulfonic acid in dry benzene under separation of the produced water as azeotropic mixture. bp $114 \sim 115^{\circ} \mathrm{C} / 24 \mathrm{mmHg}$. The reaction of the enamine with allylbromide at room temperature for $12 \mathrm{hr}$, followed by ordinary treatment, afforded ( \pm )-2-allylcyclopentanone, bp $188 \sim 190^{\circ} \mathrm{C}$, IR $\nu_{\max }^{\text {film }} \mathrm{cm}^{-1} ; 3060,1750,1640,1000,920$. The semicarbazone of the ketone showed $\mathrm{mp} 180^{\circ} \mathrm{C}$.

b) ( \pm )-2-Allylcyclopentanols ( $\mathrm{Va}, \mathrm{VIa}$ ). Sodium borohydride reduction of $( \pm)$-2-allylcyclopentanone in ethanol at room temperature for $12 \mathrm{hr}$ afforded 2allylcyclopentanols (Va, VIa), bp $95 \sim 105^{\circ} \mathrm{C} / 22 \mathrm{mmHg}$. IR $\nu_{\max }^{\text {film }} \mathrm{cm}^{-1} ; 3360,3060,1635,995,910$. The alcohols consisted of $34 \%$ of cis form (VIa) (ret. time: $9.5 \mathrm{~min}$ ) and $66 \%$ of trans form (Va) (ret. time: $11.8 \mathrm{~min}$ ) by gas chromatographical analysis $(2 \mathrm{~m} 20 \%$ Hyprose SP 80 on $\mathrm{C}-22$, column temp: $152^{\circ} \mathrm{C}$ isothermal, He flow rate: $\left.13 \mathrm{cc} / \mathrm{min}\left(0.92 \mathrm{~kg} / \mathrm{cm}^{2}\right)\right) . \quad n_{\mathrm{D}}^{30} 1.4662$. Also, lithium aluminum hydride reduction of the ketone in tetrahydrofuran at $5^{\circ} \mathrm{C}$ for $20 \mathrm{~min}$ afforded a mixture of cis form (VIa) $(25.7 \%)$ and trans form (Va) $(74.3 \%)$.

c) (士)-2-Allylcyclopentyl acetates $(\mathrm{Vb}, \mathrm{VIb})$. Acetylation of the alcohols (Va, VIa), prepared by $\mathrm{NaBH}_{4}$ reduction of 2-allylcyclopentanone, with acetic anhydride-pyridine afforded ( \pm )-2-allylcyclopentyl acetates ( Vb, VIb), bp $73 \sim 80^{\circ} \mathrm{C} / 5 \mathrm{mmHg}, n_{\mathrm{D}}^{28} 1.4470$. IR $\nu_{\max }^{f_{\mathrm{ilm}}} \mathrm{cm}^{-1} ; 3060,1740,1240,1020,915$. Retention time: $8.2 \mathrm{~min}$ for $\mathrm{Vb}$ and $8.8 \mathrm{~min}$ for $\mathrm{VIb}$ on gas chromatography using the same column and condition as used in 5) b).

6) Microbial hydrolysis of ( \pm -2-allylcyclopentyl acetates (Vb, VIb) by Bacillus subtilis var. niger

The acetates $(\mathrm{Vb}, \mathrm{VIb})(7.0 \mathrm{~g})$ were treated with a cultured broth of B. subtilis $(500 \mathrm{ml})$ at $27^{\circ} \mathrm{C}$ for 3 days. Steam-distillation of the cultured broth, followed by ether extraction, afforded an oil, which consisted of $62 \%$ of 2-allylcyclopentanols and $38.1 \%$ of 2-allylcyclopentyl acetate by gas chromatographical analysis. Alumina column chromatography of the oil afforded $(+)-2-$ allylcyclopentyl acetates, a mixture of VIIb and VIIIb (about $3: 7$ ) $[\alpha]_{\mathrm{D}}^{23}+8.5^{\circ}$ (homog), by elution with benzene, and (-)-2-allylcyclopentanols (VIIa, VIIIa), $[\alpha]_{\mathrm{D}}^{23}-3.5^{\circ}$ (homog). Fraction of the alcohols $(1.9 \mathrm{~g})$ was chromatographed on alumina $(50 \mathrm{~g})$. Elution with benzene $(100 \mathrm{ml})$ gave $32 \mathrm{mg}$ of a mixture of VIIIa $(64 \%)$ and VIIa $(36 \%)[a]_{D}^{20}-2.5^{\circ} \quad(c=1.0$ in $n$-hexane $)$. Successive elution with benzene afforded trans alcohol (VIIa) $[\alpha]_{\mathrm{D}}^{20}-4.0^{\circ} \quad(c=2.0$ in $n$-hexane). IR (VIIa) $\nu_{\text {max }}^{\text {fim }} \mathrm{cm}^{-1} ; 3340,3080,1640,1080,1000,980,920$. $p$-Nitrobenzoate of VIIa: oil.

7) Isopropyl (土)-trans and cis-chrysanthemates (IXC and $X c)$

(士)-trans-Chrysanthemyl chloride was reacted with isopropyl alcohol in pyridine at $5^{\circ} \mathrm{C}$ for several hours to give isopropyl ( \pm )-trans-chrysanthemate (IXc), bp $122 \sim 124^{\circ} \mathrm{C} / 25 \mathrm{mmHg}$. IR $\nu_{\max }^{\mathrm{fllm}} \mathrm{cm}^{-1} ; 1725,1285,1235$, $1200,1170,1110,915,865$. Similarly, the reaction of (士)-cis-chrysanthemyl chloride with isopropyl alcohol in pyridine afforded isopropyl (土)-cis-chrysanthemate (Xc), bp $122 \sim 125^{\circ} \mathrm{C} / 25 \mathrm{mmHg}$. IR $\nu_{\max }^{\mathrm{flim}} \mathrm{cm}^{-1} ; 1725$, $1180,1145,1110,1085,920$.

8) Treatment of $( \pm)$-cis and trans chrysanthemates $(I X b, I X c, X b$ and $X c)$ by Trichoderma $s p$.

Firstly, $6.0 \mathrm{~g}$ of methyl (土)-trans-chrysanthemate (IXb), prepared by methylation of IXa with diazomethane in ether, was shaken with the cultured broth of Trichoderma sp. which was cultured in the glucose phosphate peptone medium $(200 \mathrm{ml})$ under shaking at $27^{\circ} \mathrm{C}$ for 3 days. After shaking at $27^{\circ} \mathrm{C}$ for 4 days, steam-distillation of the cultured broth, followed by ether extraction and washing with aqueous $\mathrm{NaHCO}_{3}$, afforded $3.0 \mathrm{~g}$ of $\mathrm{IXb},[\alpha]_{\mathrm{D}}^{15} \quad 0.0^{\circ} \quad(c=30$ in EtOH $)$. Similarly, treatment of methyl $( \pm)$-cis-chrysanthemate (Xb) with the cultured broth of Trichoderma sp. afforded the racemic ester (Xb). Secondly, the transisopropyl ester (IXc) $(5.5 \mathrm{~g})$ was shaken with the cell free solution of Trichoderma $\mathrm{sp}$. which was cultured in $200 \mathrm{ml}$ of the glucose phosphate peptone medium at $27^{\circ} \mathrm{C}$ for 3 days under shaking. After shaking for 4 days, extraction of the above mixture with ether afforded $5.2 \mathrm{~g}$ of the ester (IXc), $[\alpha]_{\mathrm{D}}^{15} \quad 0.0^{\circ} \quad(c=15$ in $\mathrm{EtOH}$ ), and $60 \mathrm{mg}$ of acidic fraction, $[\alpha]_{\mathrm{D}}^{15} 0.0^{\circ}$ (in EtOH) which was methylated with diazomethane in ether to give methyl esters consisting of $81.5 \%$ of IXb (ret. time: $8.3 \mathrm{~min}$ ) and $16.2 \%$ of an unknown compound (ret. time: $12.0 \mathrm{~min}$ ) by gas chromatographical analysis ( $1.5 \mathrm{~m} \mathrm{30 \%}$ SE 30 , column temp: $150^{\circ} \mathrm{C}, \mathrm{He}, 0.5 \mathrm{~kg}$ l $\left.\mathrm{cm}^{2}\right)$. Similarly, treatment of the cis-isopropyl ester (Xc) $(5.0 \mathrm{~g})$ with the cell free solution of Trichoderma sp. $(200 \mathrm{ml})$ afforded the ester $(\mathrm{Xc}),[\alpha]_{\mathrm{D}}^{10} 0.0^{\circ}(c=10 \mathrm{in}$ EtOH $)(4.8 \mathrm{~g})$ and an acidic fraction $(50 \mathrm{mg}),[\alpha]_{\mathrm{D}}^{10}$ $0.0^{\circ}$ (in EtOH). Esterification of the acidic fraction with diazomethane afforded $\mathrm{Xb}$ (ret. time: $4.4 \mathrm{~min}$ ) contaminated with an unknown compound $(7.4 \%)$ (ret. time: $6.6 \mathrm{~min}$ ) by gas chromatographical analysis $\left(1.5 \mathrm{~m} \mathrm{30} \% \mathrm{SE} 30,170^{\circ} \mathrm{C}, \mathrm{He}, 0.5 \mathrm{~kg} / \mathrm{cm}^{2}\right)$.

\section{9) Enzymatic hydrolysis of (土)-trans-chrysanthemyl acetate $(X I b)$}

$( \pm)$-trans-Chrysanthemyl acetate (XIb) was prepared by $\mathrm{LiAlH}_{4}$ reduction of Xla in ether at $5 \mathrm{C}$ followed by acetylation with acetic anhydride-pyridine. bp 103 $103.5^{\circ} \mathrm{C} / 17 \mathrm{mmHg}, n_{\mathrm{D}}^{23} 1.4572$. IR $\nu_{\max }^{\mathrm{film}} \mathrm{cm}^{-1} ; 1745$, $1380,1240,1130,1030,980$. The acetate (XIb) $(2.0 \mathrm{~g})$ was shaken with $500 \mathrm{mg}$ of crude esterase, separated from the cultured broth of Trichoderma sp. ${ }^{11}$ in $100 \mathrm{ml}$ of water at $27^{\circ} \mathrm{C}$ for 2 days. Extraction of the reaction mixture with ether afforded an oil, which consisted of $34.1 \%$ of trans-chrysanthemyl acetate (ret. time: 3.7 
min) and $65.9 \%$ of trans-chrysanthemyl acetate (ret. time: $5.7 \mathrm{~min})$ by gas chromatographical analysis $(1.5 \mathrm{~m}$ $\left.30 \% \mathrm{SE} 30,172^{\circ} \mathrm{C}, \mathrm{He}, 17 \mathrm{cc} / \mathrm{min}\right)$. Alumina column chromatography of the oil afforded $987 \mathrm{mg}$ of (t)trans-chrysanthemyl acetate, $[\alpha]_{D}^{19}+2.2^{\circ} \quad(c=9.8$ in $\mathrm{EtOH})$ and $395 \mathrm{mg}$ of (-)-trans-chrysanthemyl alcohol, $[\alpha]_{D}^{19}-11.4^{\circ}\left(c=3.9\right.$ in EtOH) (Ref.,,$\left.^{5}[\alpha]_{\mathrm{D}}^{27}+46^{\circ}\right)$.

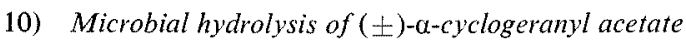
(XIII) by Bacillus subtilis var. Niger

( \pm )- $a$-Cyclogeranyl acetate (XIII) was prepared by $\mathrm{LiAlH}_{4}$ reduction of methyl ( \pm )- $\alpha$-cyclogeranate (XII) in ether followed by acetylation with acetic anhydridepyridine. bp $106 \sim 109^{\circ} \mathrm{C} / 23 \mathrm{mmHg}, n_{\mathrm{D}}^{15} 1.4678$. NMR $\left(\mathrm{CCl}_{4}\right) \delta: 0.90(3 \mathrm{H}, s), 0.93(3 \mathrm{H}, s), 1.71(3 \mathrm{H}, s), 1.91$ $(3 \mathrm{H}, s), 3.95(2 \mathrm{H}, t), 5.27(1 \mathrm{H}, m)$. The acetate (XIII) $(1.5 \mathrm{~g})$ was treated with the cultured broth of $B$. subtilis $(100 \mathrm{ml})$ for $27^{\circ} \mathrm{C}$ for 2 days. Steam-distillation of the cultured broth afforded $1.3 \mathrm{~g}$ of an oil, which consisted of $28.4 \%$ of XIVa (ret. time: $2.9 \mathrm{~min}$ ) and $71.6 \%$ of $\mathrm{XIVb}$ (ret. time: $4.8 \mathrm{~min}$ ) by gas chromatographical analysis $\left(1.5 \mathrm{~m} 30 \% \mathrm{SE} 30,174^{\circ} \mathrm{C}\right.$, He: $\left.13 \mathrm{cc} / \mathrm{min}\right)$. Alumina column chromatography of the oil afforded $874 \mathrm{mg}$ of XIVb, $[\alpha]_{D}^{20}+9.2^{\circ}(c=8.7 \mathrm{in} \mathrm{EtOH})$ and 290 $\mathrm{mg}$ of XIVa, $[\alpha]_{\mathrm{D}}^{30}-17.2^{\circ}\left(c=2.9\right.$ in EtOH). (Ref. ${ }^{6 !}$ : $\left.[a]_{D}^{35}-132.1^{\circ}(\mathrm{EtOH})\right)$.

11) Asymmetrical hydrolysis of ( \pm )-3,5,5-trimethylcyclohex-3-enyl acetate $(X V)$ by Bacillus subtilis var. Niger

The acetate (XV) $(10 \mathrm{~g})$ was added to 1 liter of the cultured broth of $B$. subtilis, which was cultured in 1 liter of the nutrient broth medium at $27^{\circ} \mathrm{C}$ for 3 days. After shaking for 2 days, steam-distillation of the cultured broth afforded $7.8 \mathrm{~g}$ of an oil, which consisted of the alcohol (XVIa) $(45.0 \%$, ret. time: $2.2 \mathrm{~min})$ and 55.0 $\%$ of the acetate (XVIb) (ret. time: $4.1 \mathrm{~min}$ ) by gas chromatographical analysis $\left(1.5 \mathrm{~m} 30 \% \mathrm{SE} 30,142^{\circ} \mathrm{C}\right.$, $\mathrm{He} ; 23 \mathrm{cc} / \mathrm{min}$ ). Alumina column chromatography of the oil afforded (-)-3,5,5-trimethylcyclohex-3-enol $(\mathrm{XVIa}),[a]_{\mathrm{D}}^{19}-144^{\circ}$ (homog) and $(+)-3,5,5$-trimethylcyclohex-3-enyl acetate (XVIb), $[\alpha]_{D}^{19}+76^{\circ}$ (homog).

\section{2) Epoxidation of $(+)-3,5,5$-trimethylcyclohex-3-enyl acetate $(X V I b)$}

Perbenzoic acid $(4.1 \mathrm{~g})$ in chloroform $(10 \mathrm{ml})$ was added to a stirred solution of XVIb $(4.15 \mathrm{~g})$ in $50 \mathrm{ml}$ of chloroform at $5^{\circ} \mathrm{C}$. After standing overnight, the solution was washed with aqueous $\mathrm{NaHCO}_{3}$ and dried over anhyd. $\mathrm{MgSO}_{4}$. Evaporation of the solvent afforded an oil, which was chromatographed on $70 \mathrm{~g}$ of neutral alumina. Elution with $n$-hexane afforded $1.45 \mathrm{~g}$ of (+)-cis-3,4-epoxy-3,5,5-trimethylcyclohexyl acetate (XVIIa), $[\alpha]_{\mathrm{D}}^{10}+5.0^{\circ}(c=2.5$ in $n$-hexane). Successive elution with $n$-hexane gave $1.5 \mathrm{~g}$ of epoxides which consisted of $67.9 \%$ of XVIIa (ret. time: $8.5 \mathrm{~min}$ ) and $32.1 \%$ of XVIIb (ret. time: $9.3 \mathrm{~min}$ ) by gas chro- matographical analysis $\left(2 \mathrm{~m} \times 3 \mathrm{~mm} 20 \%\right.$ DEGS $165^{\circ} \mathrm{C}$, $\mathrm{He}, 15 \mathrm{cc} / \mathrm{min})$. Continued elution with benzeneether $(1: 1)$ gave $(+)$-trans-3,4-epoxy-3,5,5-trimethylcyclohexyl acetate (XVIIb) $(177 \mathrm{mg}),[\alpha]_{\mathrm{D}}^{10}+6.8^{\circ}(c=$ 2.5 in $n$-hexane). NMR (XVIIa) $\left(\mathrm{CCl}_{4}\right) \delta: 2.20(3 \mathrm{H}, s)$, $2.28(3 \mathrm{H}, s), 2.64(3 \mathrm{H}, s), 3.94(3 \mathrm{H}, s), 3.88(1 \mathrm{H}, s)$, $9.54(1 \mathrm{H}, m)$. NMR (XVIIb) $\left(\mathrm{CCl}_{4}\right) \delta: 2.16(3 \mathrm{H}, s)$, $2.24(3 \mathrm{H}, s), 2.68(3 \mathrm{H}, s), 3.93(3 \mathrm{H}, s), 4.98(1 \mathrm{H}, s)$.

13) Rearrangement of (+)-3,4-epoxy-3,5,5-trimethylcyclohexyl acetates ( $X V I I a, X V I I b$ ) with $\mathrm{MgBr}_{2}$

The epoxy-acetates (XVIIa, XVIIb) $(1.4 \mathrm{~g})$ in $100 \mathrm{ml}$ of dry ether were refluxed with $90 \mathrm{ml}$ of magnesiumbromide etherate, prepared from $0.3 \mathrm{~g}$ of $\mathrm{Mg}$, and $2.16 \mathrm{~g}$ of $\mathrm{HgBr}_{2}$ in $90 \mathrm{ml}$ of ether-benzene (2:1), for $3.5 \mathrm{hr}$. The reaction mixture was washed with dil. $\mathrm{H}_{2} \mathrm{SO}_{4}$ and then aqueous $\mathrm{NaHCO}_{3}$. Evaporation of the solvent afforded $1.2 \mathrm{~g}$ of crude acetoxy-ketone (XVIIIb') bp $100 \sim 105^{\circ} \mathrm{C} / 10 \mathrm{mmHg}, n_{\mathrm{D}}^{18} 1.4663$, which consisted of $82.4 \%$ of XVIIIb' (ret. time: $8.2 \mathrm{~min}$ ) and $17.6 \%$ of an unknown compound (ret. time: $9.9 \mathrm{~min}$ ) by gas chromatographical analysis (column: $2 \mathrm{~m} \times 3 \mathrm{~mm} \mathrm{20 \%}$ DEGS, column temp: $175^{\circ} \mathrm{C}$ isothermal, He flow rate: $20 \mathrm{cc} / \mathrm{min}$ ). Alumina column chromatography of the crude ketone (XVIIIb') afforded pure (-)-trans4-acetoxy-2,2,6-trimethylcyclohexanone (XVIIIb') as an oil, $[\alpha]_{\mathrm{D}}^{10}-5.3^{\circ}\left(c=5.7\right.$ in $n$-hexane). $\mathrm{NMR}\left(\mathrm{CCl}_{4}\right) \delta$ : $0.99(3 \mathrm{H}, d, J=6 \mathrm{~Hz}), 1.05(3 \mathrm{H}, s), 1.25(3 \mathrm{H}, s), 2.03$ $(3 \mathrm{H}, s), 2.85(1 \mathrm{H}, m), 5.03(\mathrm{IH}, m, \mathrm{~W} 1 / 2$ value $=8 \mathrm{~Hz}$, $e-\mathrm{H})$. Deacetylation of XVIIIb' by treatment with sodium methoxide in methanol for $12 \mathrm{hr}$ afforded (-)cis-4-hydroxy-2, 2, 6-trimethylcyclohexanone (XIXa'), $[c]_{D}^{10}-10.0^{\circ} \quad\left(c=4.0\right.$ in $\left.\mathrm{CHCl}_{3}\right)$. NMR $\left(\mathrm{CCl}_{4}\right) \delta: 0.99$ $(3 \mathrm{H}, d, J=6 \mathrm{~Hz}), 1.03(3 \mathrm{H}, s), 1.20(3 \mathrm{H}, s), 3.25(1 \mathrm{H}$, $s, \mathrm{OH}), 4.18(1 \mathrm{H}, m, \mathrm{~W} 1 / 2$ value $=15 \mathrm{~Hz}, a-\mathrm{H}), p-$ Nitrobenzoate of XIXa'; mp $132 \sim 133^{\circ} \mathrm{C}$ (from $n$ hexane), $[\alpha]_{\mathbb{D}}^{11}-5.0^{\circ}\left(c=1.0\right.$ in $\left.\mathrm{CHCl}_{3}\right)$.

\section{4) Preparation of $( \pm)$-trans-4-acetoxy-3,3,5-trimethyl-} cyclohexanone $(X X I I b)$

Lithium aluminum hydride reduction of 4-monoethylene ketal of XX in ether followed by treatment with dilute sulfuric acid, afforded $( \pm)$-trans-4-hydroxy-3,3,5trimethylcyclohexanone (XXIIa), mp $75^{\circ} \mathrm{C}$ (from $n$ hexane-benzene). NMR $\left(\mathrm{CCl}_{4}\right) \delta: 0.84(3 \mathrm{H}, s), 1.07$ $(3 \mathrm{H}, s), 1.09(3 \mathrm{H}, d, J=6 \mathrm{~Hz}), 1.89(1 \mathrm{H}, m), 2.14(4 \mathrm{H}$, $m), 2.87(1 \mathrm{H}, s, \mathrm{OH}), 3.25(1 \mathrm{H}, \mathrm{W} 1 / 2$ value $=11 \mathrm{~Hz})$.

15) Sodium borohydride reduction of the diketone $(X X)$ A solution of $\mathrm{NaBH}_{4}(360 \mathrm{mg})$ in $\mathrm{H}_{2} \mathrm{O}(20 \mathrm{ml})$ and EtOH $(40 \mathrm{ml})$ was added dropwise to a stirred solution of XX $(5.5 \mathrm{~g})$ in $60 \mathrm{ml}$ of $\mathrm{EtOH}$ at $10^{\circ} \mathrm{C}$ for $15 \mathrm{~min}$. After stirring for $12 \mathrm{hr}$ at room temperature, the reaction mixture was acidified with dilute $\mathrm{H}_{2} \mathrm{SO}_{4}$ and extracted with ether. Evaporation of the solvent afforded an oil $(5.6 \mathrm{~g})$, which consisted of $2.5 \%$ of XX (ret. time: 
$7.8 \mathrm{~min}$ ), about $3.0 \%$ of XVIIa, $23.0 \%$ of XIXa (ret. time: $15.8 \mathrm{~min}$ ), $71.5 \%$ of XXIIa and probably a small amount of XXIa, (ret. time: $18.3 \mathrm{~min}$ ) by gas chromatographical analysis $(2 \mathrm{~m} \times 3 \mathrm{~mm} \mathrm{20 \%}$ DEGS, $175^{\circ} \mathrm{C}, \mathrm{He} ; 20 \mathrm{cc} / \mathrm{min}$ ) (Fig. 1). Similarly, reduction of $\mathrm{XX}(7.7 \mathrm{~g})$ in $70 \mathrm{ml}$ of $\mathrm{EtOH}$ with $\mathrm{NaBH}_{2}(\mathrm{O}$-isopropyl $)_{2}$, prepared from $0.95 \mathrm{~g}$ of $\mathrm{NaBH}_{4}, 2.9 \mathrm{~g}$ of acetone in $50 \%$ aqueous EtOH $(120 \mathrm{ml})$, afforded a mixture of hydroxy-ketones $(4.0 \%$ of XVIIIa, $24.0 \%$ of XIXa, $72.0 \%$ of XXIa and XXIIa) by gas chromatographical analysis. Alumina column chromatography of the above ketones afforded XXIIa, mp $76 \sim 77^{\circ} \mathrm{C}$ by elution with benzene-ether. Also, silica-gel column chromatography of the ketones afforded XXIIa by elution with benzene-ethyl acetate and then pure ( \pm cis-4-hydroxy-2,2,6-trimethylcyclohexanone (XIXa) as an oil, which was identical with $\mathrm{XIXa}^{\prime}$ by comparison with their NMR spectra. $p$-Nitrobenzoate, mp $138^{\circ} \mathrm{C}$ (from $n$-hexane-benzene), Anal. Found: C, 63.21; $\mathrm{H}$, 6.32; N, 4.45. Calcd for $\mathrm{C}_{16} \mathrm{H}_{19} \mathrm{O}_{5} \mathrm{~N}: \mathrm{C}, 62.94 ; \mathrm{H}$, $6.27 ; \mathrm{N}, 4.45 \%$. Successive elution with ethyl acetate gave a small amount of diol, $\mathrm{mp} 117 \sim 118^{\circ} \mathrm{C}$ (from benzene). IR $v_{\max }^{\text {film }} \mathrm{cm}^{-1} ; 3320,1380,1260,1165,1080$, $1055,1040,1020,1000,950,940$. NMR $\left(\mathrm{CDCl}_{3}\right) \tilde{0}$ : $0.99(3 \mathrm{H}, s), 1.09(3 \mathrm{H}, d), 1.50(3 \mathrm{H}, s), 2.90(1 \mathrm{H}, d, J=$ $10 \mathrm{~Hz}), 4.02(1 \mathrm{H}, m), 4.64(2 \mathrm{H}, s, 2 \mathrm{OH})$.

16) Separation of the acetoxy-ketones (XIXb,XXIb and $X X I I b)$ by alumina column chromatography

The acetoxy-ketones $(7.5 \mathrm{~g})$, obtained by acetylation of ( \pm )-hydroxy-ketones (XIXa, XXIa and XXIIa) (sample in 15)) with acetic anhydride-pyridine, was chromatographed on neutral alumina $(170 \mathrm{~g})$. Elution with $n$-hexane-benzene $(1: 1)$ afforded $2.9 \mathrm{~g}$ of XIXb (as the first fraction), NMR $\left(\mathrm{CCl}_{4}\right) \hat{o}: 0.99(3 \mathrm{H}, d, J=$ $6 \mathrm{~Hz}), 1.05(3 \mathrm{H}, s), 1.25(3 \mathrm{H}, s), 1.95(3 \mathrm{H}, s), 5.22(1 \mathrm{H}$, $m, \mathrm{Wh}=33 \mathrm{~Hz}, a-\mathrm{H}$ ), and then $1.4 \mathrm{~g}$ of a mixture of XIXb, XXIb and XXIIb (as the second fraction). Successive elution with benzene afforded $2.19 \mathrm{~g}$ of ( \pm )trans-4-acetoxy-3,3,5-trimethylcyclohexanone (XXIIb), $\mathrm{mp} 45^{\circ} \mathrm{C}$ (from $n$-hexane). NMR $\left(\mathrm{CCl}_{4}\right) \delta: 0.90(3 \mathrm{H}$, $s), 0.91(3 \mathrm{H}, d, J=5 \mathrm{~Hz}), 2.02(3 \mathrm{H}, s), 4.84(1 \mathrm{H}, d, J=$ $11 \mathrm{~Hz}$ ). Alumina column chromatography of the second fraction afforded (土)-cis-4-acetoxy-3,3,5-trimethylcyclohexanone (XXIb) (contaminated with a small amount of XXIIb). NMR $\left(\mathrm{CCl}_{4}\right) \delta: 0.92(3 \mathrm{H}, s)$, $0.98(3 \mathrm{H}, d), 2.02(3 \mathrm{H}, s), 4.40(1 \mathrm{H}, d, J=10 \mathrm{~Hz})$. Retention time of the acetoxy-ketones: $9.1 \mathrm{~min}$ for XIXb and XVIIIb', $11.1 \mathrm{~min}$ for XXIb and $12.9 \mathrm{~min}$ for XXIIb on gas chromatography using a $2 \mathrm{~m} \times 3 \mathrm{~mm}$ stainless steel column packed with $20 \%$ DEGS on celite 545, column temp: $175^{\circ} \mathrm{C}$ isothermal, $\mathrm{He}$ flow rate: $20 \mathrm{cc} / \mathrm{min}$.

17) Enzymatic hydrolysis of the acetoxy-ketones (XIXb, $X X I b$ and $X X I I b)$
The acetoxy-ketones $(2.0 \mathrm{~g}$, a mixture of XIXb $(66.3$ $\%)$ XXIb $(13.7 \%)$ and XXIIb $(20.0 \%)$ were shaken with $500 \mathrm{mg}$ of crude esterase (produced by Trichoderma sp.) in $100 \mathrm{ml}$ of water at $27^{\circ} \mathrm{C}$ for 2 days. The reaction mixture was extracted with ether. Evaporation of the solvent afforded an oil, which was consisted of $55.0 \%$ of XIXb", $13.7 \%$ of XXIb, $20.0 \%$ of XXIIb and $11.3 \%$ of XIXa' by gas chromatographical analysis. The oil was chromatographed on alumina $(50 \mathrm{~g})$. Elution with $n$-hexane-benzene afforded $458 \mathrm{mg}$ of a mixture of XIXb" $(73.0 \%)$, XXIIb (16.6\%) and XXIb (10.4\%), $[\alpha]_{D}^{12}+7.6^{\circ}(c=9.2$ in $n$-hexane) and then $588 \mathrm{mg}$ of a mixture of $\mathrm{XIXb}^{\prime \prime}, \mathrm{XXIb}$ and XXIIb. Successive elution with benzene afforded $70 \mathrm{mg}$ of XXIb contaminated with a small amount of XXIIb. Elution with ether-ethanol afforded $324 \mathrm{mg}$ of XIXa', $[\alpha]_{\mathrm{D}}^{12}-16.6^{\circ}$ ( $c=1.8$ in $\mathrm{CHCl}_{3}$ ), which was reacted with dihydropyran by using $p$-toluenesulfonic acid in benzene at room temperature to give THPether of XIXa', $[\alpha]_{\mathrm{D}}^{12}$ $-2.0^{\circ}\left(c=5.5\right.$ in $\left.\mathrm{CHCl}_{3}\right)$ (Ref. ${ }^{8)}$ : its antipode, $[\alpha]_{\mathrm{D}}^{19}+$

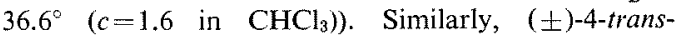
acetoxy-3,3,5-trimethylcyclohexanone dissolved in small amount of toluene was not hydrolyzed by the crude esterase in water.

\section{8) Hydrogenation of the diketone $(X X)$}

The diketone $(X X)(7.7 \mathrm{~g})$ in $40 \mathrm{ml}$ of methanol was hydrogenated with Adams' catalyst $(400 \mathrm{mg}$ ) at room temperature (atomospheric pressure) for 2 days. The obtained product was chromatographed on alumina. Elution with benzene afforded a starting material (XX) $(4.0 \mathrm{~g})$. Successive elution with ether-ethanol afforded a mixture of hydroxy-ketones (XVIIIa, XIXa and XXIIa) (2.8 g) although some samples were lost by sublimation during evaporation of the solvents. IR $\nu_{\max }^{\text {film }} \mathrm{cm}^{-1} ; 3420,1710,1060,1035,995,910$. The hydroxy-ketones consisted of $16.4 \%$ of XVIIIa (ret, time: $14.7 \mathrm{~min}$ ), $37.3 \%$ of XIXa (ret. time: $16.2 \mathrm{~min}$ ) and $46.3 \%$ of XXIIa (ret. time: $18.5 \mathrm{~min}$ ) by gas chromatographical analysis $\left(20 \% \mathrm{DEGS}, 176^{\circ} \mathrm{C}, \mathrm{He}, 20\right.$ cc/min) (Fig. 2). The hydroxy-ketones were treated with sodium methoxide in methanol at room temperature for $24 \mathrm{hr}$ to give a mixture of XIXa and XXIIa mainly, which were acetylated with acetic anhydridepyridine to afford a mixture of two acetoxy-ketones (XIXb and XXIIb), which were also separated to each component by alumina column chromatography.

Acknowledgement. The authors express their thank to Miss T. Endou for measurements of NMR spectra. Thanks are due to Sumitomo Chemical Co., Ltd. for suppling chrysanthemic acid and allethrolone.

\section{REFERENCES}

1) T. Oritani and K. Yamashita, Agr. Biol. Chem., 
37, 1687, 1691, 1695 (1973).

2) T. Oritani and K. Yamashita, Agr. Biol. Chem., 38, 1965 (1974).

3) R. J. Barker and L. N. Edmunds, J. Econ. Entomol., 2, 56 (1963).

4) F. B. Laforge, N. Green and M. S. Schechter, J. Org. Chem., 19, 457 (1954).

5) L. Crombie and J. Crossley, J. Chem. Soc., 1963, 4983; H. C. Rilling, C. D. Poulter, W. W. Epstein and B. Larsen, J. Amer. Chem. Soc., 93, 1783
(1971).

6) C. H. Eugster, R. Bucheker, C. H. Tscharner, G. Uhde and G. Ohloff, Helv. Chim. Acta, 52, 1729 (1969).

7) T. Oritani and K. Yamashita, Agr. Biol. Chem., 37, 1215 (1973).

8) K. Mori, Tetrahedron Letters, 723, 2635 (1973).

9) F. Hoffman, LaRoche Co., A. G. Brit. Pat., 790, 607; See C. A., 52, 15575d (1958). 